\title{
KAJIAN MAKNA DAN FUNGSI TEMBANG BAWA METRUM DANDANGGULA DALAM LAGU CAMPURSARI
}

\section{STUDY OF MEANING AND FUNCTION OF BAWA SONG USING DANDANGGULA POETIC METER ON CAMPURSARI SONG}

\author{
Bagus Wahyu Setyawan'; Yusuf Muflikh Raharjo ${ }^{b}$ \\ aUniversitas Islam Negeri Sayyid Ali Rahmatullah Tulungagung \\ Jalan Mayor Sujadi No. 46, Kudusan, Plosokandang, Kec. Kedungwaru, Kabupaten Tulungagung, \\ Jawa Timur, Indonesia 66221 \\ bUniversitas Terbuka, \\ Jalan Cabe Raya, Pondok Cabe, Kec. Pamulang, Kota Tangerang Selatan, Jawa Barat, Indonesia \\ 15437 \\ bagusws93@gmail.com
}

(Naskah diterima tanggal 6 Juni 2020, direvisi terakhir tanggal 8 November 2021, dan disetujui tanggal 10 November 2021)

DOI: https:/ / doi.org/10.26499/wdprw.v49i2.557

\begin{abstract}
Bawa as a one of literary song like a sindhenan, janturan, gerongan, and palaran. Firstly bawa song used in Javanese traditional or karawitan music, but since 1970 th bawa song start to used in other genre, such as campursari. This research aimed to describe and analyse the meaning and function of bawa song in campursari. Sample on this research taken from bawa song with dandanggula poetic meter, that are bawa of kanca tani, pepeling, and nyidham sari song. Data collected technique using record-note and in-depth interview with some informant. Data analysis of this research using qualitative-interactive with the phase are data reduction, data display, and conclusion drawing. Result of this research find that bawa on campursari song have function as intro before song sing in. Therefore, bawa also represented the meaning and message of the campursari song. So, the lyric of bawa song have suitability with content of campursari song. Bawa song in this era also have attract power on campursari fans, because there are some dialogue between bawa singer with other singer, $M C$, or some audience which contain sense of joke inside.
\end{abstract}

Keywords: study meaning and function; bawa song; dandanggula poetic meter; campursari song

\begin{abstract}
Abstrak
Bawa merupakan salah bentuk sastra tembang seperti halnya sindhenan, janturan, gerongan, dan palaran. Awalnya bawa digunakan untuk musik-musik karawitan, tetapi mulai tahun 1970-an tembang bawa mulai merambah dalam genre musik campursari. Penelitian ini bertujuan untuk menganalisis makna dan fungsi tembang bawa dalam lagu campursari. Sampel yang digunakan adalah tembang bawa bermetrum dandanggula, yaitu bawa langgam kanca tani, pepeling, dan nyidham sari. Pengumpulan data menggunakan teknik simak-catat dan wawancara mendalam dengan narasumber. Analisis data dalam penelitian ini menggunakan analisis interaktif kualitatif dengan tahapan reduksi data, sajian data, dan penarikan simpulan. Hasil dari penelitian ini ditemukan bahwa tembang bawa dalam lagu campursari berfungsi sebagai intro atau awalan sebelum masuk lagu. Selain itu bawa juga merepresentasikan makna atau kandungan isi dari lagu campursari. Jadi, lirik tembang bawa memiliki kesepadanan dan kesesuaian makna dengan isi dari lagu campursari. Tembang bawa di era sekarang juga menjadi daya tarik bagi penikmat lagu
\end{abstract}


campursari, karena terdapat dialog antara pelantun bawa dengan penyanyi lain, $\mathrm{MC}$, bahkan dengan penonton yang kerap kali mengandung unsur humor.

Kata-kata kunci: kajian makna dan fungsi; tembang bawa; metrum dandanggula; lagu campursari

\section{Pendahuluan}

Berbicara mengenai tembang bawa tidak dapat dilepaskan dengan tembang macapat, mengingat salah satu bentuk dari tembang bawa adalah tembang macapat. Tembang bawa yang biasa digunakan berasal dari tembang gedhe (sekar ageng), tembang tengahan (sekar tengahan), dan tembang macapat (sekar macapat) (Martopangrawit, 1975: 1). Tembang macapat merupakan tembang Jawa yang digolongkan dalam puisi gagrak lawas. Hal ini disebabkan masih terdapat konvensi yang mengikat atau aturan baku dalam tembang macapat. Tembang macapat adalah salah satu puisi Jawa yang menggunakan bahasa Jawa baru, dan masih terikat dengan persajakan atau metrum, yang terdiri dari guru gatra, guru wilangan, dan guru lagu (Budiarti, 2008: 2). Tembang macapat termasuk karya sastra Jawa tradisional. Ketradisionalannya terletak pada aturannya yang ketat, yakni terikat pada aturan guru gatra yakni jumlah baris pada setiap bait, terikat guru lagu yakni bunyi vokal pada akhir setiap baris dan terikat guru wilangan yakni jumlah suku kata pada setiap baris (Nugroho, 2018: 75). Konvensi tersebut membuat bentuk tembang macapat menjadi baku, kaku, dan memiliki ciri khas atau pembeda yang jelas. Hal itu berbeda dengan puisi gaya baru dalam sastra Jawa disebut geguritan yang cenderung lebih bebas dan tidak terikat konvensi. Jenis puisi yang tidak memenuhi konvensi baku seperti aturan dan metrum tidak bisa disebut dengan tembang macapat.

Tembang macapat dipandang sebagai salah satu kekayaan khas sastra daerah yang lahir dari penafsiran, ekspresi jiwa yang imajinatif, dan idealisasi pengarangnya terhadap kehidupan sosial masyarakat yang dituangkan ke dalam komposisi dan struktur artistik (Suarta, 2018: 192). Muatan isi dalam tembang macapat juga tidak jauh dari kehidupan sosial masyarakat, bisa berupa nasehat atau petuah tentang kehidupan, berisi tentang sistem nilai, kearifan lokal, mitos, ramalan, ungkapan perasaan, juga tidak jarang menggambarkan tentang terjadinya suatu peristiwa. Tembang macapat juga merupakan representasi kesenian tradisi Jawa yang harus dilestarikan karena menunjang usaha pengembangan kebudayaan nasional. Tembang macapat kebanyakan ditulis dalam bentuk serat oleh para pujanggapujangga yang berasal dari Keraton di Jawa. Sampai sekarang karya sastra berupa serat yang berisi tembang macapat masih dapat ditemukan di beberapa museum keraton dan beberapa museum yang memiliki konsentrasi dan perhatian terhadap karya sastra Jawa klasik.

Tembang macapat memiliki sisi keindahan dan estetika dilihat dari cara membacanya, yaitu harus sesuai dengan cengkok dan laras dari tembang macapat yang ditembangkannya. Membaca tem-bang macapat sama saja dengan menembangkan tembang macapat sesuai dengan cengkoknya. Cengkok dan titi laras tembang macapat menjadi acuan dalam menembangkan tembang macapat. Setiap titi laras dan cengkok memiliki variasi, hal ini yang menjadikan tembang macapat memiliki nilai estetika. Adanya variasi titi laras dan cengkok ini menyebabkan si penembang ketika akan menembangkan tembang macapat harus menguasai beberapa ceng- 
kok dan titi laras yang berbeda, walaupun jenis tembang yang ditembangkan memiliki metrum yang sama. Berkaitan dengan titi laras, tembang macapat pada dasarnya seperti seni musik barat yang memiliki titi laras dan tangga nada terdiri dari dua macam, yaitu pelog dan slendro, sementara itu struktur menyesuaikan watak tembang yang telah memiliki pakem (aturan baku), seperti gatra (baris), pada (bait), guru wilangan (jumlah kata dalam setiap baris), guru lagu (jatuhnya huruf vokal dan akhir baris), dan pupuh (jumlah bait) (Surbono dan Sutiyono 2018). Konvensi baku dalam tembang macapat tersebut menjadikan tembang macapat memiliki suatu kekhasan yang menjadikannya berbeda dengan karya seni, khususnya lagu.

Dalam perkembangannya, tembang macapat mulai merambah dan digunakan dalam berbagai kesenian Jawa lainnya, seperti dalam sindhenan, sulukan, palaran, bawa, dan digunakan dalam pementasan opera Jawa. Termasuk di dalamnya tembang bawa, apabila tembang bawa tersebut berbentuk tembang macapat, maka akan mengikuti konvensi dan metrum seperti tembang macapat. Tembang bawa memiliki bentuk dan metrum yang berbedabeda. Bentuk dan metrum tembang bawa mengacu pada metrum yang terdapat dalam tembang macapat, termasuk bahasa yang digunakan dalam tembang bawa. Bahasa yang digunakan hampir sama dengan bahasa yang digunakan dalam tembang macapat, yaitu menggunakan ragam bahasa Jawa baru, walaupun terdapat beberapa kata atau leksikon yang diambil dari bahasa Kawi atau bahasa Jawa Kuna.

Bawa kerap diidentikkan dengan pembawaan dan kewibawaan. Pembawaan di sini disebabkan setiap orang ketika melantunkan bawa memiliki ciri khas tersendiri, baik itu dalam hal warna suara, teknik vokal yang digunakan, penjiwaan, dan gestur atau ekspresi ketika membawakan tembang bawa. Berkaitan dengan kewibawaan, yaitu mengenai kewibawaan dari tembang bawa itu sendiri. Suyoto, Haryono, dan Hastanto dalam tulisannya mengemukakan bahwa tembang bawa merupakan tembang tunggal atau mandiri yang penuh kewibawaan untuk memulai sajian gendhing (2015: 37). Selain itu, kewibawaan tembang bawa berkaitan dengan sejarah tembang bawa yang pada mulanya dinyanyikan oleh kaum laki-laki atau pria. Para penyanyi bawa zaman dahulu merupakan pria atau wiraswara, yang pada saat membawakan bawa dianggap memiliki wibawa karena suaranya yang terbilang bagus.

Masih berkaitan dengan sejarah tembang bawa, Daladi mengemukakan bahwa sebelum tahun 1970-an tembang bawa hanya disajikan pada musik-musik tertentu, semisal klenengan, santiswaran, dan larasmadya (dalam Suyoto dkk., 2015). Akan tetapi, setelah tahun 1970-an tembang bawa mulai masuk dalam pertunjukkan wayang purwa, yaitu pada saat adegan limbukan dan gara-gara. Dalam kesenian larasmadya, tembang bawa merupakan salah satu tembang yang dinyanyikan oleh penyanyi tanpa diiringi oleh musik (Adzkia, 2016: 7). Fungsinya adalah sebagai intro atau baitbait pembuka sebelum masuk gendhing. Pada periode sekarang, tembang bawa sudah merambah tidak hanya pada keseniankesenian yang sudah disebutkan di atas, tetapi sudah merambah pada kesenian lainnya. Salah satu ragam musik yang di dalamnya terdapat penggunaan tembang bawa, adalah musik campursari dan langgam Jawa.

Musik campursari apabila dirunut dari asal katanya berasal dari kata campur dan sari. Campur berarti penggabungan dua atau lebih unsur yang berlaian atau bukan sejenis menjadi sebuah unsur atau bentuk 
baru. Istilah campur sari sendiri merupakan berbaurnya instrumen musik tradisional dengan alat musik modern sehingga menghasilkan irama yang lain dari yang lain (Kobi, 2017: 11). Campursari dikenal pada awal tahun 1970-an, pada saat itu memperdengarkan siaran musik gabungan dari alat pentatonis dan diatonis. Sejarah musik berangkat dari musik keroncong asli langgam, oleh karenanya apabila ditinjau lebih mendalam musik campursari masih menggunakan dasardasar keroncong. Musik campursari pada awalnya dipopulerkan oleh Ki Nartosabdo, seorang seniman pembaharu dalam dunia pewayangan dan musik tradisional Jawa. Musik campursari diaransemen oleh Ki Nartosabdo dengan menggabungkan musik modern dengan musik gamelan sehingga menghasilkan harmoni dengan nuansa tradisi Jawa.

Instrumen musik campursari merupakan percampuran instrumen musik yang terdiri dari beberapa unsur dasar karawitan, keroncong atau langgam, dan musik pop. Piranti atau alat musik yang digunakan dalam musik campursari juga merupakan campuran antara instrumen gamelan (gong, kendhang, saron, bonang, gender) dengan alat musik modern (gitar, bas, organ, drum, dll). Musik yang dihasilkan dari kesenian campursari ini juga merupakan perpaduan antara kedua unsur tersebut dan dalam penyajiannya lebih luwes karena bisa menjangkau berbagai genre musik, baik itu keroncong, langgam, pop, maupun genre musik lain seperti reggae, dangdut, musik rok, maupun musik jazz. Oleh karena itu, musik campursari dapat menjangkau dan dinikmati oleh berbagai kalangan. Dalam perkembangannya, musik campursari memiliki fungsi yang sangat sentral di masyarakat. Ada dua macam fungsi, yaitu fungsi primer meliputi; (1) sebagai sarana ritual, (2) sarana hiburan pribadi, dan (3) sebagai prosentase estetis. Selanjutnya, fungsi sekunder musik campursari apabila dipilah dapat menjadi sembilan fungsi, yaitu; (1) sebagai pengikat solidaritas kelompok, (2) sebagai pembangkit rasa solidaritas bangsa, (3) sebagai media komunikasi bangsa, (4) sebagai media propaganda keagamaan, (5) sebagai media pro-paganda politik, (6) sebagai media propaganda program-program pemerintah, (7) sebagai media meditasi, (8) sebagai sarana terapi, dan (9) sebagai perangsang produktivitas. Jadi, bisa dikatakan musik campursari memiliki fungsi yang sangat banyak bagi kehidupan masyarakat Jawa.

Dari awal perkembangannya sampai sekarang, industri musik campursari semakin berkembang seiring dengan perkembangan pasar dan terus berinovasi. Fenomena tersebut juga menjadikan minat masyarakat terhadap musik campursari menjadi naik. Hal ini dapat dilihat dengan semakin seringnya musik campursari ditampilkan pada acara-acara yang bersifat masal, seperti hajatan, pentas dangdut, peringatan hari jadi suatu daerah, hingga pementasan wayang kulit juga mulai menampilkan musik campursari dalam adegan limbukan ataupun gara-gara. Pada pementasan musik campursari, beberapa diantaranya menggunakan tembang bawa pada awal sebelum masuk ke dalam lagu.

Fenomena penggunaan tembang bawa dalam lagu campursari pada masa sekarang sudah bukan merupakan hal yang asing. Hampir disetiap pembawaan atau penampilan lagu campur sari terselip satu atau dua macam tembang bawa di dalamnya. Namun, yang perlu menjadi perhatian adalah penggunaan tembang bawa tidak ditemukan di semua lagu campursari. Hanya beberapa saja lagu campursari yang diawali dengan tembang bawa. Selain itu, dalam lagu campursari, 
tembang bawa yang digunakan hanya terbatas pada tembang macapat, tidak menggunakan sekar ageng atau sekar tengahan (Suyoto dkk., 2015: 38). Oleh karena itu, perlu diadakan penelitian dan pembahasan yang lebih mendalam mengenai makna dan fungsi tembang bawa dalam lagu campursari. Penelitian ini untuk mempertegas dan mengkaji secara lebih mendalam mengenai makna dari tembang bawa, hubungannya dengan muatan dan maksud lagu campursari. Selain itu, penelitian ini juga mengkaji fungsi sebenarnya dari tembang bawa yang terdapat dalam beberapa lagu campursari. Hal ini mengingat fenomena penggunaan tembang bawa dalam lagu campursari sudah menjadi budaya masyarakat Jawa yang sangat marak dalam setiap pementasan lagu campursari.

\section{Metode Penelitian}

Bentuk penelitian ini adalah penelitian kualitatif deskriptif. Kualitatif deskriptif adalah penelitian yang berdasarkan data deskriptif (Zakaria \& Listiyaningsih, 2016: 580). Artinya data tersebut berupa lisan atau tertulis dari subjek penelitian yang telah diamati dan memiliki karakteristik bahwa data yang diberikan merupakan data asli yang tidak diubah. Data dalam penelitian ini berupa lirik tembang bawa dari beberapa lagu campursari. Sampel yang dipilih adalah tembang bawa yang bermetrum dandanggula saja. Penentuan sampel ini bertujuan untuk memudahkan dalam analisis data yang dilakukan atau dapat dikatakan teknik pengambilan sampel menggunakan teknik purposive sampling. Strategi yang digunakan dalam penelitian ini adalah strategi penelitian terpancang (embedded research), yaitu penelitian kualitatif yang sudah menentukan fokus penelitian sehingga variabel utama atau subjek penelitian dikaji ber- dasarkan pada tujuan dan minat peneliti yang sudah ditentukan sebelumnya (Sutopo, 2002: 42). Penelitian ini memiliki fokus tujuan untuk meneliti makna dan fungsi tembang bawa dalam lagu campursari.

Analisis data dalam penelitian ini menggunakan teknik analisis dokumen (content analysis). Definisi analisis dokumen menurut Holsti adalah teknik yang digunakan untuk menarik simpulan melalui usaha menemukan karakteristik pesan dan dilakukan secara objektif dan sistematis (Moleong, 2014: 220). Langkahlangkah yang diterapkan, dengan cara mereduksi data dari keseluruhan data, yaitu memilih beberapa lirik tembang bawa dari semua sampel tembang bawa yang berbentuk tembang macapat. Setelah itu masih dilakukan pemilihan, yaitu memilih hanya tembang bawa yang bermetrum tembang dandanggula. Akhirnya, ditentukan 3 sampel penelitian, yaitu cakepan atau lirik tembang bawa dari langgam kanca tani, pepeling, dan nyidham sari yang semuanya menggunakan bawa dengan metrum dandanggula. Teknik analisis dalam penelitian ini yang pertama menggunakan analisis semiotik, dengan menggunakan pembacaan heuristik dan hermeneutik. Pembacaan heuristik oleh Pradopo didefinisikan sebagai teknik membaca yang didasarkan pada konvensi bahasa untuk menemukan serangkaian arti yang masih bersifat heterogen (2010: 269). Teknik ini hanya didasarkan pada makna secara gramatikal saja. Selanjutnya, teknik hermeneutik menurut pandangan Teeuw adalah pembacaan yang sudah merujuk pada ditemukannya makna secara utuh atau terpadu dari suatu teks (Nurgiyantoro, 2018: 33). 


\section{Hasil dan Pembahasan}

\subsection{Makna Tembang Bawa Bermetrum Dandanggula}

Setiap karya sastra pasti mempunyai makna atau maksud yang ingin disampaikan oleh si pembuat karya sastra itu. Sama seperti halnya dengan tembang macapat ataupun tembang bawa pasti juga memiliki makna. Lirik tembang bawa sebagai salah satu karya sastra yang mengandung ajaran moral, yang apabila dicerna dan dimaknai secara lebih mendalam dapat dijadikan acuan manusia dalam penerapan di kehidupannya (Wahid \& Saddhono, 2017: 173). Hal tersebut juga ditegaskan oleh Herawati bahwa setiap karya seni selalu ingin menyampaikan pesan moral, baik dalam hal politik, spiritual, pendidikan, maupun pesan moral. Pesan-pesan tersebut dapat bisa diketahui dari cakepan tembang macapat (Heriwati, 2016: 114). Cakepan mempunyai arti lirik atau syair tembang macapat. Cakepan atau lirik oleh si pembuat tembang dibuat dengan merangkai kata-kata yang mempunyai arti dan harus diterjemahkan oleh si pembaca atau pelantun tembang macapat. Perlu diketahui bahwa dalam menerjemahkan syair atau lirik tembang macapat tidak bisa hanya sepotong-sepotong, tetapi harus utuh, karena antara satu gatra dengan yang lainnya memiliki kesinambungan makna.

Cara menerjemahkan makna dari tembang bawa dapat dilakukan dengan menggunakan analisis semiotik. Semiotik seperti dikemukakan oleh Pradopo adalah konsep mempelajari sistem-sistem, aturan-aturan, konvensi-konvensi yang memungkinkan suatu tanda-tanda mempunyai arti (Pradopo, 2010: 980). Secara terminologi, semiotika adalah ilmu yang mempelajari sederetan luas objek-objek, peristiwaperistiwa dalam suatu kebudayaan sebagai tanda (Huda, Hamim, \& Wibowo, 2018: 7). Untuk mener-jemahkan suatu teks dengan menggunakan pendekatan semiotik maka digunakan dua penafsiran, yaitu penafsiran secara heuristik dan herme-neutik. Metodologi analisis dengan menggunakan semiotika berdasarkan leksia, yaitu berupa satu kata, kalimat, atau sebuah paragraf, dan kode-kode dalam menelaah suatu cerita. Pemenggalan kalimat dari sebuah teks dibebaskan bagi pembaca. Hal tersebut dikarenakan satuan-satuan kalimat yang telah dipilah merupakan sebuah rekonstruksi yang dilakukan oleh pembaca sehingga teks terbuka terhadap penafsiran baru (Surbono \& Sutiyono, 2018: 44).

Berbicara mengenai Tembang bawa memiliki banyak macamnya, mulai dari sekar ageng, sekar tengahan, sampai sekar macapat. Bawa yang berbentuk sekar macapat juga beragam, ada yang berbentuk tembang sinom, pocung, pangkur, dandanggula, asmaradana, dan yang lainnya. Tembang bawa yang dianalisis dalam artikel ini adalah tembang bawa yang bermetrum dandanggula. Tembang Dandanggula menggambarkan keadaan kehidupan manusia yang telah mencapai tahap kemapanan sosial, kesejahteraan telah tercapai dan telah menikmati masa hidupnya. Kata dhandang berarti burung gagak yang melambangkan kesedihan atau duka. Kata gula berarti gula yang mempunyai rasa manis sebagai lambang kebahagiaan atau suka (Heliarta, 2009: 45). Setiap keluarga dalam masyarakat Jawa harus mampu melampaui kehidupan berumah tangga yang terkadang manis seperti gula, tetapi terkadang mereka juga harus mau untuk menelan pil pahit sebagai obat untuk menjadikan mereka lebih tatag, tangguh, tanggon, dan tanggap dalam setiap keadaan (Budiono \& Wiratama, 2017: 1347). Dangdanggula, membawakan suasana yang serba manis, menyenangkan, santai, dan mengungkapkan rasa kasih. Tembang dandanggula diciptakan oleh Sunan Kalijaga 
untuk mengajarkan rasa manis yang berarti mengharap kebahagiaan (Darsono, 2016: 34). Metrum dandanggula seperti diungkapkan oleh Limbong mempunyai kandungan tematik "mengharap supaya baik". Selain itu, metrum ini memiliki kandungan tematik yang manis, lembut dan menyenangkan sehingga sering digunakan untuk membingkai sebuah wacana yang mengandung ajaran-ajaran (Limbong, 2015: 425). Metrum atau tembang dandanggula terdiri dari 10 baris dengan guru lagu dan guru wilangan yang sudah pakem, yaitu 10i, 10a, 8e, 7u, 9i, 7a, 6u, $8 a, 12 i, 7 a$. Cengkok yang dimiliki oleh tembang dandanggula berjumlah 28 cengkok. Berikut akan ditafsirkan makna dari ketiga tembang bawa yang menjadi objek penelitian dalam artikel ini.

\subsubsection{Makna Tembang Bawa Langgam Kanca Tani}

Langgam Kanca Tani merupakan lagu ciptaan musisi campursari terkenal Manthous. Manthous merupakan salah satu tokoh campursari yang sangat produktif menciptakan lagu-lagu campursari. Terhitung mulai tahun 1993-2002, Manthous dan grup campursarinya, yaitu Campursari Gunungkidul (CSGK) menciptakan lebih dari 100 lagu, salah satunya adalah langga Kanca Tani yang menjadi objek penelitian dalam penelitian ini. Langgam Kanca Tani ini diciptakan dengan pola campuran antara langgam Jawa konvensional dan lelagon kreasi baru. Pada bagian introduksi, langgam Kanca Tani ini menggunakan pengantar tembang bawa. Bedanya, bawa pada lagu ini dengan bawa pada karawitan lainnya adalah bawa Kanca Tani ini berdiri sendiri, tidak langsung diterima oleh gendhing, sehingga setelah bawa tidak dilanjutkan celuk, akan tetapi dilanjutkim introduksi musik (Kusnadi, 2006: 120). Titilaras yang digunakan dalam
Langgam Kanca Tani karangan Manthous ini adalah titilaras Pelog Nem. Berikut ini lirik bawa langgam Kanca Tani ciptaan Manthous.

Ilir-ilir tandure sumilir
Kanca tani kang padha makarya
Sinawung lejar atine
Parine lemu-lemu
Katon subur nyenengke ati
Kalis ing sambekala
Iku panyuwunku
Wit sih ing gusti kawula
Kanca tani yekti saka guru nagri
Uga betenging bangsa

Apabila diterjemahkan secara heuristik atau berdasarkan pada konvensi kebahasaan yang sebenarnya, makna dari bawa Kanca Tani tersebut adalah sebagai berikut.

- Ilir-ilir tandure sumilir: terlihat hamparan tumbuhan padi yang luas tertiup angin. Hal ini sesuai dengan konteks lagu Kanca Tani yang menceritakan tentang kehidupan petani. Lirik bawa pada baris pertama ini memberikan citra dan gambaran kepada pembaca ataupun pendengar tembang bawa tentang tanaman padi di sawah yang tertiup angin. Lirik bawa ini juga diambil dari tembang ilir-ilir karangan Sunan Kalijogo. Manthous mengambil salah satu lirik lagu ilir-ilir dikarenakan untuk memberikan nuansa budaya Jawa yang kental.

- Kanca tani kang padha makarya: para petani sedang bekerja (makarya di sini juga dapat diartikan sedang menggarap sawahnya). Setelah menggambarkan keadaan tanaman padi yang mulai menguning dan tertiup angin, pada baris kedua ini digambarkan mengenai aktivitas para petani yang sedang bekerja menggarap sawahnya. Hal tersebut disesuaikan dengan isi dan judul lagu Kanca Tani.

- Sinawung lejar atine: bersamaan dengan hati yang senang (lejar berate senang, tanpa beban, gembira, sedangkan atine 
mengilustrasikan suasana hati dari sang petani). Pengarang menggambarkan para petani yang menggarap sawah dengan hati yang senang. Penggambaran ini oleh pengarang tidak terlepas dari latar belakang sosial pengarang yang berasal dari Kabupaten Gunungkidul yang mayoritas penduduknya berprofesi sebagai petani. Aspek latar sosiologis dari Manthous sangat kental di lirik ini melalui penggambaran suasana hati petani yang menggarap sawah dengan senang hati.

- Parine lemu-lemu: padinya terlihat gemuk. Baris ini mengilustrasikan tentang tanaman padi yang ditanam oleh petani dan terlihat gemuk. Gemuk disini berarti tanaman padi yang ditanam tumbuh dengan baik sehingga menghasilkan tanaman yang gemuk-gemuk, dilihat dari pohonnya dan dari segi bijinya yang sangat besar.

- Katon subur nyenengke ati: terlihat subur menentramkan hati (yang dimaksud subur di sini adalah tumbuhan yang tumbuh di sawah dan pekarangan para petani). Baris ketiga memiliki koherensi dengan baris sebelumnya. Tanaman padi yang subur dapat membuat semangat para petani dalam menggarap sawahnya dan membuat senang hati.

- Kalis ing sambekala: terhindar dari malapetaka dan bahaya (kalis bisa berarti terhindar atau dijauhkan, sedangkan sambekala merupakan dasanama dari bahaya, barang yang tidak baik, musibah, dll). Baris ini merupakan pengaharapan dari petani ketika menggarap sawahnya, yatu terhindar dari mara bahaya. Oleh karenanya, dalam budaya Jawa sebelum menanam padi melakukan upacara tandur yang merupakan representasi dari sikap gotong royong masyarakat Jawa.

- Iku panyuwunku: itu permintaanku. Makna pada baris ini memiliki korelasi dengan baris sebelumnya, yaitu tentang permintaan petani ketika menggarap sawahnya supaya terbebas dari marabahaya, hama, dan hal-hal yang tidak baik. Pengaharapan petani ini juga terkait dengan hasil panen yang melimpah dari sawah yang digarapnya.

- Wit sih ing Gusti Kawula: karena mendapat anugrah tuhan (wit di sini bukan berarti pohon, tapi merupakan cekakan dari kata wiwit. Sama seperti halnya dengan kata sih, yang merupakan cekakan dari asih atau kasih). Aspek spiritual juga sangat kental dalam tembang bawa langgam Kanca Tani, hal ini dibuktikan pada baris ini. Walaupun para petani sudah berusaha dengan maksimal, tetapi pengharapan akan hasil tetap dipasrahkan kepada Tuhan (Gusti Kawula). Kondisi ini juga menegaskan bahwa masyarakat Jawa, khususnya para petani tidak bisa menggarap sawahnya dengan baik dan dapat menghasilkan panen yang sangat melimpah kalau tidak mendapat anugerah dan belas kasih dari Tuhan.

- Kanca tani yekti saka guru nagri: petani yang menjadi tonggak pe-nyangga Negara (saka guru dalam rumah adat Jawa berarti penyangga yang mempunyai peran penting, biasanya berjumlah 4 atau 8. Jadi, para petani diibaratkan menjadi penyangga kehidupan Negara). Indonesia merupakan Negara agraris yang masyarakatnya dominan menggantungkan hidupnya dari pertanian. Oleh karenanya, petani merupakan salah satu profesi yang memiliki peran vital untuk menunjang perekonomian dan kehidupan berbangsa serta bernegara (Saheb, Slamet, \& Zuber, 2018: 134). Apabila tidak ada petani yang menggarap sawah, maka masyarakat Indonesia bisa kekurangan bahan pangan, mengingat makanan pokok sebagian besar masyarakat Indonesia adalah nasi yang berasal dari tanaman padi.

- Uga bentenging bangsa: juga sebagai pelindung Negara. Pernyataan pada baris ini merupakan penegasan baris selanjutnya, yaitu tentang peran para petani sebagai salah satu unsur penyokong kehidupan berbangsa dan bernegara. Hal ini dikarenakan petani merupakan unsur penentu roda kehidupan berbangsa dan bernegara. Dianggap benteng dan pe- 
lindung negara karena peran petani sebagai penyedia makanan pokok masyarakat Indonesia. Apabila tidak ada jasa dan peran petani maka masyarakat Indonesia tidak akan mendapatkan kebutuhan pangan dengan layak. Buntut dari situasi tersebut akan panjang dan berdampak kompleks terhadap aktivitas di segala sektor dari Negara Indonesia.

Apabila ditinjau secara hermeneutik makna dari bawa tersebut adalah menceritakan kehidupan profesi petani yang ketika bekerja menggarap ladang dan sawahnya dengan hati gembira. Hal ini dikarenakan mereka saling membantu dan gotong royong ketika menggarap sawahnya. Faktor lain adalah kondisi sawah dan ladang yang subur juga dapat menyenangkan hati para petani. Gambaran mengenai kehidupan petani ini tidak terlepas dari latar belakang sosiologis dari pencipta tembang bawa Kanca Tani, yaitu Manthous yang berasal dari salah satu daerah di Kabupaten Gunungkidul, di Provinsi Daerah Istimewa Yogyakarta yang mayoritas masyarakatnya berprofesi sebagai petani. Aspek spiritual juga sangat kental dalam tembang bawa Kanca Tani, karena salah satu barisnya menyebutkan bahwa kondisi tanah yang subur dan hasil panen yang melimpah semata-mata karena anugrah dari Tuhan. Pengarang lagu juga berpendapat bahwa para petani memiliki peran penting dalam Negara, diibaratkan sebagai penyangga dan benteng Negara yang menyediakan kebutuhan bahan pangan bagi masyarakat luas.

\subsubsection{Makna Tembang Bawa Langgam Pepeling}

Suatu tembang atau nyanyian Jawa dalam proses penciptaannya pasti memiliki maksud yang ingin disampaikan kepada para pendengar dan khalayak umum. Suatu lirik lagu Jawa merupakan salah satu karya sastra sehingga dapat disimpulkan bahwa lirik lagu Jawa atau tembang juga mengandung ajaran moral. Lirik tembang Jawa yang mengandung ajaran moral dapat dibagi menurut jenis-jenis ajaran moralnya sehingga dapat ditemukan inti ajaran yang bisa lebih dicerna manusia dalam penerapan di kehidupannya (Wahid \& Saddhono, 2017: 173). Langgam Pepeling merupakan suatu tembang langgam yang diciptakan dan digubah oleh salah satu dalang yang berasal dari daerah Surakarta, yaitu Ki Anom Suroto. Ki Anom Suroto merupakan dalang yang sudah melanglang buana di dunia kesenian dan dunia pewayangan. Tembang Pepeling sering diperdengarkan dalam acara pementasan campursari ataupun dalam pengajian. Lirik lagunya memiliki makna yang mendalam, khususnya bagi umat Islam. Langgam Pepeling mengajarkan kepada umat Islam untuk melaksanakan ibadah shalat yang merupakan salah satu perintah agama dengan sepenuh hati dan istiqomah. Apabila diartikan secara harfiah, makna kata "pepeling" adalah pengingat. Pengingat di sini dimaksudkan tembang Pepeling ini dapat memberikan pengingat kepada umat Islam untuk selalu ingat dan melaksanakan salat dengan sepenuh hati dan istiqomah. Secara lebih mendalam makna dari tembang bawa Langgam Pepeling adalah sebagai berikut.

Rukun islam kang lima puniki
Katindakna mring para sasama
Aja padha ditinggalke
Rukun islam puniku
Sadat loro kang angka siji
Kang angka loro shalat
Iku kang katelu
Romadon nindakna pasa
Papat zakat, kelima ngibadah haji
Rukun islam sampurna

Rukun islam kang lima puniki

Katindakna mring para sasama

Aja padha ditinggalke

Rukun islam puniku

Sadat loro kang angka siji

Kang angka loro shalat

Iku kang katelu

Romadon nindakna pasa

Rukun islam sampurna 
Secara heuristik makna dari syair bawa di atas adalah sebagai berikut:

- Rukun islam kang lima puniki: rukun Islam yang jumlahnya ada lima. Baris pertama ini menegaskan bahwa rukun Islam ini ada lima. Hal ini tidak terlepas dari arti judul lagu, yang berarti pengingat. Jadi, isi tembang bawa Langgam Pepeling ini merupakan pengingat, terutama pengingat tentang rukun Islam yang jumlahnya ada lima.

- Katindakna mring para sasama: ditujukan dan harus dilakukan oleh umat Islam (pra sasama dalam konteks ini ditujukan kepada semua umat islam). Rukun Islam ini ditujukan dan wajib dilaksanakan oleh orang yang beragama Islam. Jadi, maksud dari kata pra sasama adalah ditujukan untuk semua umat Islam, terutama umat Islam yang sudah masuk dalam kategori balig atau sudah mencukupi usia.

- Aja padha ditinggalke: jangan sampai ditinggalkan. Sifat dari rukun Islam adalah bersifat wajib, khususnya untuk orang Islam yang sudah balig atau cukup umur. Baris ini merupakan imbauan kepada para umat Islam supaya tidak lupa dan meninggalkan rukun Islam yang berjumlah lima.

- Rukun islam puniku: rukun Islam adalah sebagai berikut. Baris ini merupakan pengantar untuk menjelaskan tentang perincian rukun Islam yang berjumlah lima.

- Sadat loro kang angka siji: Dua kalimat syahadat yang pertama (sadat merupakan cekakan dari kata syahadat, hal ini digunakan karena untuk menyesuaikan dengan konvensi guru wilangan dari tembang dandanggula). Baris ini menjelaskan mengenai rukun Islam yang pertama, yaitu dua kalimat syahadat. Syahadat terdiri dari dua kalimat, yaitu syahadat tauhid dan syahadat rasul. Syahadat ini merupakan penegasan dan kesaksian terhadap sifat ketuhanan Allah Swt dan kerasulan Nabi Muhammad saw.
Kang angka loro shalat: yang nomor dua salat. Salat merupakan ibadah wajib bagi umat muslim yang merupakan rukun Islam yang kedua. Salat sehari-semalam dilaksanakan sejumlah lima kali, yaitu Subuh, Zuhur, Ashar, Magrib, dan Isyak. Salat merupakan ibadah yang fundamental bagi masyarakat Islam karena dalam konsep agama Islam, indikator ibadah orang muslim ditentukan oleh baik atau tidaknya salatnya. Selain itu, salat merupakan ibadah yang pertama kali dihitung pada saat hari kiamat.

- $\quad$ Iku kang katelu: selanjutnya yang ketiga.

- Romadhon nindakna pasa: pada saat Bulan Ramadan hendaknya menjalankan ibadah puasa. Puasa Ramadan merupakan ibadah wajib yang harus dilakukan oleh umat Islam. Pada Bulan Ramadan seluruh umat Islam disarankan untuk memperbanyak ibadah dan amal saleh, salah satu ibadah wajib yang harus dikerjakan pada saat Bulan Ramadan adalah puasa. Puasa yang dimaksud adalah menahan makan, minum, dan segala yang membatalkannya mulai dari fajar sampai waktu Magrib. Puasa tidak hanya sebagai sarana latihan kekuatan raga semata, tetapi juga untuk melatih jiwa dan hati menahan hal-hal yang tidak baik serta dilarang oleh agama (Basalamah 2018). Dalam kepercayaan masyarakat Jawa, puasa juga merupakan salah satu sarana laku atau tapa yang harus dilakukan ketika akan mendapatkan sebuah keinginan atau cita-cita yang diidam-idamkan.

- Papat zakat, kelima ngibadah haji: nomor empat zakat dan rukun Islam yang kelima ibadah haji. Zakat adalah memberikan sebagian harta kepada golongan yang membutuhkan. Golongan penerima zakat diidentifikasi ada delapan golongan, yaitu fakir, miskin, amil, muallaf, hamba sahaya, gharimin, fisabilillah, dan ibnu sabil. Masyarakat Jawa yang beragama Islam diwajibkan untuk membayar zakat fitrah yang dilaksanakan di Bulan Ramadan. Zakat dilakukan untuk membersihkan sebagian harta dan rezeki yang diterima, 
karena dalam kepercayaan agama Islam, terdapat jatah orang lain di sebagian harta yang diterima. Hal ini bertujuan untuk melatih kepekaan masyarakat Jawa terhadap masyarakat sekitar. Selain itu, dengan menunaikan zakat dapat memberikan dorongan untuk memberi dan membantu orang lain yang sedang kesusahan (Siahaan, 2019: 3). Baris ini juga menjelaskan mengenai ibadah haji yang merupakan rukun Islam yang kelima atau yang terakhir. Ibadah haji ini di-lakukan dengan mengunjungi Ka'bah di Tanah Suci Mekkah. Ibadah haji merupakan ibadah yang wajib di-lakukan oleh orang Islam apabila termasuk dalam kategori mampu, mampu di sini diartikan mampu secara fisik, finansial, dan kondisi mental. Hal ini dikarenakan biaya untuk melakukan ibadah haji tidak murah dan dibutuhkan fisik serta mental yang kuat untuk bisa menunaikan ibadah haji di Mekkah. Oleh karenanya, banyak yang mengatakan bahwa ibadah haji merupakan ibadah yang hanya bisa dilakukan dengan hidayah dan anugerah dari Allah, karena untuk melakukannya tidaklah mudah.

- Rukun Islam sampurna: apabila dapat melaksanakan kelima rukun Islam tersebut, maka akan dikatakan sempurna. Baris terakhir dalam tembang bawa Pepeling ini memberikan sebuah penegasan bahwa apabila masyarakat Jawa yang beragama Islam dapat menjalankan semua hal yang dianjurkan dalam Islam mulai dari syahadat, menunaikan salat, berpuasa di Bulan Ramadan, mengeluarkan zakad

Apabila diartikan secara luas, makna dari tembang bawa pepeling tersebut bertujuan untuk mengingatkan kepada para umat Islam akan pentingnya rukun Islam. Dari yang pertama syahadat, salat, puasa, zakat, dan naik haji. Kesemuanya ditujukan kepada seluruh umat Islam dan harus dijalankan dengan penuh ketaatan. Apabila dapat menjalankan semuanya maka akan sempurna rukun Islamnya. Isi dari tembang bawa pepeling tersebut juga tidak bisa dilepaskan dari maksud dan tujuan diciptakannya Langgam Pepeling oleh Ki Anom Suroto, yaitu untuk dapat memberikan pengingat atau pangeling-eling kepada masyarakat luas, khususnya masyarakat yang beragama Islam. Hal ini juga memiliki korelasi dengan isi dari syair lagu Langgam Pepeling yang menceritakan tentang ibadah shalat dan pengingat kepada masyarakat tentang pentingnya menjalankan syariat agama Islam.

\subsubsection{Makna Tembang Bawa Langgam Nyidham Sari}

Langgam Nyidham Sari merupakan lagu karangan dari seniman keroncong, yaitu Andjar Any. Apabila dirunut dari judulnya, kata Nyidham atau ngidham artinya sangat mengidam-idamkan sesuatu. Istilah nyidham ini biasanya dikhususkan kepada wanita yang sedang hamil. Wanita hamil seringkali menginginkan sesuatu dengan sangat kuatnya, terutama makanan, misalnya rujak, buah berasa asam, durian, dsb. Keinginan kuat seperti ini disebut nyidham atau ngidham. Sari yang dimaksud adalah 'sari bunga' atau lebih tepatnya madu atau sari madu. Seperti yang telah diketahui, lagu-lagu yang diciptakan Andjar Any tidak jauh dari ungkapan kasih cintanya pada istri yang sangat ia cintai, yaitu "Piyatni", kebanyakan lagu ciptaan Andjar Any memang didedikasikan untuk sang istri (Ranabumi, 2018: 249). Syair lagu ini penuh dengan perumpamaan, peribahasa, yang secara bahasa sangat indah, menawan, dan sangat membekas di hati pendengarnya, sehingga banyak orang 'jatuh cinta pada pendengaran pertama'. Peribahasa di sana, bermuara pada pujian, pujaan, dambaan kepada seorang wanita. Secara lebih mendalam makna dari tembang bawa Langgam Nyidham Sari adalah sebagai berikut. 
Dhuh wong ayu pepujaning ati

Kaya ngene rasane wong nandhang asmara

Apa ta awakku dhewe

Dhuh dewa jawata gung

Welasana mring wak mami

Mbesuk kapan kasembadan

Jejer lang wong ayu

Umpamakna nahkodha

Tanpa prau sasat barat ing jaladri

Nyidham sari asmara

- Dhuh wong ayu pepujaning ati: duhai wanita cantik yang menjadi pujaan hati. Baris pembuka dalam tembang bawa langgam Nyidham Sari ini menandakan bahwa tembang atau lagu ini ditujukan kepada seorang wanita. Hal ini dapat dilihat dari kata "wong ayu" yang mengindikasikan sifat seorang wanita, ayu dalam bahasa Jawa berarti cantik. Selanjutnya, kata pepujaning ati bermakna pujaan hati. Jadi, jelas sekali bahwa lagu ini ditujukan kepada seorang wanita yang menjadi pujaan hati dari si pengarang, Andjar Any.

- Kaya ngene rasane wong nandhang asmara: seperti ini rasanya kalau sedang jatuh cinta. Baris ini merupakan ungkapan hati dari Andjar Any yang mengekspresikan ketika dirinya sedang jatuh cinta. Dari konteks tersebut dapat diketahui bahwa pengarang lagu ketika menciptakan lagu ini dalam suasana hati yang sedang jatuh cinta yang diekspresikan menjadi sebuah syair tembang bawa.

- Apa ta awakku dhewe: apa hanya aku sendiri? Pengarang lagu, dalam hal ini Andjar Any bertanya mengenai perasaan yang dialami, apakah hanya dialami oleh dirinya sendiri atau memang dialami oleh wanita yang menjadi pujaan hatinya. Makna lain dari konteks kalimat tersebut, juga menandakan bahwa perasaan jatuh cinta dialami oleh pengarang lagu sendiri, tidak dialami oleh orang lain. Jadi, pengarang lagu mengekspresikan perasaannya sendiri, bukan dari cerita atau perasaan orang lain.

- Dhuh dewa jawata gung: Duh dewa penguasa alam (Jawata berarti alam, gung ber- arti besar. Apabila dimaknai dewa jawata gung, adalah dewa yang mempunyai kuasa besar untuk menguasai alam). Konteks kalimat pada baris ini, pengarang mencoba mengomunikasikan perasaan yang dialaminya kepada Tuhan, yang disimbolkan dengan leksikon Dewa Jawata Gung atau dalam bahasa Jawa bermakna Dewa Penguasa Alam. Jadi, ungkapan perasaan cinta yang dialami oleh pengarang dicoba untuk dikomunikasikan kepada Tuhan.

- Welasana mring wak mami: kasihanilah kepada diriku ini (wak dari kata awak yang berarti badan, sedangan mami adalah sebutan untuk diri sendiri, sama artinya dengan $a k u$, ingsun, manira). Baris ini berkorelasi dengan baris sebelumnya, yaitu pengarang mencoba mengomunikasikan perasaan yang dialaminya kepada Tuhan. Dalam pengharapannya, pengarang memohon kepada Tuhan untuk memberikan belas kasihan kepadanya, supaya rasa yang dialaminya tidak sia-sia atau tidak pupus.

- Mbesuk kapan kasembadan: besok kapan bisa terlaksana (kasembadan dari kata sembada, yang berarti terlaksana atau terwujud). Baris ini juga merupakan pengharapan dari Andjar Any, dia berharap citacita dan angan-angan mengenai perasaan cinta kepada wanita pujaan hatinya bisa terlaksana atau terwujud.

- Jejer lang wong ayu: bersanding dengan wanita cantik (dalam hal ini berarti bersanding di pelaminan atau menikah). Puncak dari sebuah perasaan cinta adalah pernikahan. Andjar Any melalui lagunya ini bermaksud mengungkapkan pengharapannya terhadap perasaan cintanya supaya dapat bersanding dengan wanita yang menjadi pujaan hatinya. Bersanding dalam konteks ini diartikan dengan menikah atau menjadi pasangan seumur hidup dari wanita yang menjadi pujaan hatinya. Jadi, kata wong ayu merupakan simbolisasi dan merujuk kepada wanita yang menjadi pujaan hati dari seorang Andjar Any. 
- Umpamakna nahkodha: diibaratkan menjadi seorang nahkoda. Perasaan cinta Andjar Any diibaratkan seluas lautan, jadi dia mengibaratkan dirinya sebagai seorang nahkoda yang me-ngendarai kapal untuk mengarungi lautan cintanya.

- Tanpa prau sasat barat ing jaladri: tidak memiliki kapal terhantam ombak badai di laut (Jaladri merupakan dasanama atau nama lain dari laut). Seorang nahkoda yang tidak mempunyai kapal sama halnya dengan seseorang yang ingin sampai pada tujuan tetapi tidak tahu bagaimana caranya dan menggunaka sarana apa. Frasa sasat barat ing jaladri, berarti terhantam ombak dan badai di lautan. Hal ini mengindikasikan bahwa perasaan cinta yang dialami oleh Andjar Any berjalan tidak gampang atau mendapat halangan dan rintangan yang sangat besar sehingga dibutuhkan perjuangan yang kuat untuk menghadapinya.

- Nyidham sari asmara: memimpikan sarisari atau benih-benih cinta. Apabila dilihat dari konteks sebelumnya, perjuangan cinta dari Andjar Any sangatlah besar dan mendapat rintangan yang sulit. Oleh karena itu, dia hanya mengharap untuk mendapatkan keajabian dan benih-benih asmara dari wanita pujaan hati yang diidam-idamkan.

Apabila diartikan secara luas dan menyeluruh lirik tembang bawa dari langgam Nyidham Sari menceritakan seseorang yang sedang jatuh cinta kepada seorang wanita yang menjadi pujaan hatinya. Perasaan cinta yang dialaminya sangatlah kuat sehingga merasakan perasaan yang belum pernah dirasakan. Dia meminta belas kasihan kepada Tuhan atau dalam konteks lirik tembang bawa tersebut dikatakan Dewa Jawata Gung. Selain itu, isi tembang bawa tersebut juga merupakan pengharapan dari pengarang lagu, pengharapan tersebut di antaranya pengharapan untuk mendapatkan belas kasihan dari Tuhan, meminta untuk dapat bersanding dengan wanita yang diidam-idamkan, berharap dapat melewati rintangan dan halangan yang menerpa kisah cintanya, dan berharap mendapat benih-benih cinta dari wanita pujaan hatinya. Perjalanan cinta dari pengarang diibaratkan seperti nahkoda yang sedang diterjang badai dan terombang-ambing di tengah lautan.

\subsection{Fungsi Tembang Bawa dalam Tem- bang Campursari}

Musik campursari di era ini merupakan salah satu genre musik yang digandrungi oleh berbagai kalangan. Hal tersebut dikarenakan bentuk kemasannya yang luwes dan praktis. Musik campursari yang memadukan instrumen gamelan dan alat musik modern seperti keyboard, bas, dan gitar memiliki kelebihan, yaitu dapat membawakan berbagai genre musik lain, seperti dangdut, keroncong, reggae, rock, dan jazz. Alasan di atas yang menjadikan tembang dan lagu campursari sekarang semakin digandrungi. Variasi penampilan lagu campursari sangatlah banyak, ada yang menggunakan buka celuk, bawa, dan beberapa juga tanpa adanya intro lagu atau langsung masuk dalam lagu.

Tembang bawa dalam lagu campursari berfungsi sebagai pembuka lagu. Hal tersebut seperti sudah diungkapkan oleh Suyoto, Haryono, dan Hastanto bahwa pada dua dasa warsa terkahir ini, tembang bawa sudah mulai masuk dalam musik campursari (2015). Walaupun bentuk yang dijsaikan masih sebatas pada bawa yang berbentuk tembang macapat. Dalam tembang campursari bawa digunakan sebagai awalan atau intro kemudian dilanjutkan dengan langgam sebagai dhawah-nya atau masuk lagu. Hal ini dikarenakan musik campursari jarang atau hampir tidak pernah menyajikan gendhing-gendhing atau iringan lagu seperti dalam iringan 
karawitan. Selain itu, adanya tembang bawa dapat digunakan sebagai sarana interaksi antara penyanyi dan pembawa acara atau bahkan dengan penonton. Hal ini dapat diketahui ketika pada saat melantunkan bawa penyanyi atau pem-bawa biasanya tidak langsung utuh menyelesaikan tembang bawa. Namun, di sela-selanya pasti terdapat dialog dengan pembawa acara atau penonton. Bahkan dialog-dialog tersebut kerap kali mengandung unsur humor yang dapat memancing gelak tawa penonton atau hadirin pada saat itu. Jadi, adanya tembang bawa dan pem-bawa dalam suatu pementasan campursari sekarang menjadi suatu daya tarik tersendiri. Bahkan para lawak atau sering disebut dhagelan sekarang harus mempunyai kemampuan khusus, yaitu bisa menyanyikan tembang bawa sebagai nilai tambah.

Selain sebagai intro atau awalan masuknya lagu campursari. Tembang bawa juga berfungsi sebagai pengantar pemahaman pendengar atau penonton mengenai isi lagu campursari yang akan dinyanyikan. Hal ini dapat dilihat dari sampel beberapa tembang bawa yang sudah dianalisis, secara garis besar menggambarkan mengenai isi atau kandungan lagu campursari. Seperti bawa kanca tani menggambarkan isi lagu dari langgam Kanca Tani yang menceritakan tentang kehidupan para petani, tembang bawa nyidham sari menceritakan mengenai kandungan lagu Nyidham Sari yang menceritakan tentang seorang yang sedang jatuh cinta kepada seseorang yang menjadi pujaan hatinya, dan tembang bawa Pepeling yang menceritakan mengenai pentingnya menjaga rukun Islam, seperti isi lagu Pepeling yang menceritakan mengenai pen-tingnya shalat. Akan tetapi, beberapa lagu campursari tidak menggunakan bawa terutama lagu-lagu campusari keluaran terbaru atau modern, seperti lagu-lagu ciptaan Cak Diqin dan Sony Joss. Kebanyakan dari lagu-lagu campursari terbaru saat ini hanya mementingkan unsur keindahan irama dan pasar saja, tetapi menihilkan unsur-unsur lain, seperti unsur etika dan estetika bahasa, serta unsur kedalaman makna atau pesan yang terkandung dalam lagu campursari. Judul-judul dan bahasa yang digunakan dalam lagu campursari di masa kini cenderung bahasa-bahasa yang lebih vulgar bila dibanding dengan lagulagu atau langgam campursari ciptaan $\mathrm{Ki}$ Narto Sabdo ataupun Manthous. Selain itu, tidak adanya bawa dalam beberapa lagu campursari juga berkaitan dengan proses penciptaannya. Karena ada beberapa seniman dalam menciptakan lagu hanya sekedarnya saja, dan menganggap hadir-nya tembang bawa dalam lagu campursari bukanlah menjadi suatu keharusan.

\section{Simpulan}

Tembang bawa merupakan tembang yang indepen dan berdiri sendiri serta memiliki kewibawaan. Hal ini disebabkan pada awalnya, para pelantun bawa adalah lakilaki, sehingga pada saat melantunkan tembang bawa terlihat berwibawa. Tembang bawa memiliki banyak bentuk, bisa berbentuk sekar ageng, sekar tengahan, maupun berbentuk sekar alit (macapat). Pada awalnya bawa hanya digunakan dalam karawitan, santiswaran, musik-musik klenengan. Akan tetapi, setelah tahun 1970-an tembang bawa sudah mulai merambah pada genre musik campursari dan menjadi semakin digandrungi. Bahkan, sekarang hadirnya tembang bawa dalam lagu campursari tidak hanya sebagai intro atau awalan lagu, tetapi juga sebagai pemikat penonton. Hal tersebut diarenakan pada saat melantunkan bawa, si pem-bawa sering kali berdialog dengan penyanyi, sindhen, $\mathrm{MC}$, maupun penonton yang kerap kali 
mengandung humor atau dhagelan, sehingga, di era sekarang untuk menjadi seorang dhagelan harus mempunyai skill tambahan, yaitu bisa melantunkan bawa.

Tembang bawa dalam lagu campursari hanya terbatas pada tembang bawa yang berbentuk tembang macapat. Oleh karena itu, tembang bawa juga harus mengikuti konvensi dan metrum dari tembang macapat. Kehadiran tembang bawa dalam musik campursari digunakan sebagai awal atau intro masuknya lagu. Selain itu, bawa juga sebagai pengantar awal pemahaman penonton dan penikmat lagu campursari mengenai kandungan isi dari lagu campursari. Hal ini dikarenakan dalam syait tembang bawa menyiratkan makna atau isi lagu campursari. Memang tidak semua lagu campursari diawali oleh tembang bawa karena pada saat proses pencipataan lagu campursari, beberapa seniman menganggap hadirnya tembang bawa tidak menjadi sesuatu yang penting dan hanya mengejar segmentasi pasar semata.

\section{Daftar Pustaka}

Adzkia, Sagaf Faozata. 2016. “Kesenian Laras Madya sebagai Materi Pelajaran Seni Budaya dalam Lima Orientasi Nilai Pendidikan Gage dan Berliner." Imaji 14(1):71-80.

https:/ / doi.org/10.21831/imaji.v14i1. 9536

Basalamah, Abbas Muhammad. 2018. "Manajemen Waktu: Kajian Hikmah Ramadhan dan Aplikasinya dalam Manajemen Modern Abbas Muhammad Basalamah." Ilmu Dan Budaya 40(56).

Budiarti, Muriah. 2008. “Sekilas Tentang Sindhenan Banyumasan." Keteg 8(2).

Budiono, Heru, and Nara Setya Wiratama.
2017. "Pendidikan Nilai dalam Tembang Macapat Dhandanggula." Jurnal Penelitian Pendidikan 9(1):134449.

Darsono, Darsono. 2016. “Beberapa Pandangan tentang Tembang Macapat." Jurnal Ketek 16(1):27-37.

Heliarta, S. 2009. "Seni Karawitan Jawa." Semarang: Aneka Ilmu.

Heriwati, S. Hesti. 2016. “Nilai-Nilai Yang Terkandung dalam Apresiasi Tembang-Tembang Jawa." Gelar 8(1).

Huda, Muhamad Miftahul, Hamim Hamim, and Judhi Hari Wibowo. 2018. "Analisis Semiotika Fotografi 'Alkisah' Karya Rio Motret (Rio Wibowo)." Representamen 3(01). https://doi.org/10.30996/.v3i01.1405

Kobi, Mohamad Fajrin. 2017. “Campursari: Bentuk Lain dari Kesenian Gamelan yang Diterima di Masa Modern." Jurnal Warna 1(1):1-20.

Kusnadi. 2006. "Melodi Dan Lirik Lagu Campursari Ciptaan Manthous." Imaji, Jurnal Seni dan Pendidikan Seni 4(1):109-23.

Limbong, Priscila Fitriasih. 2015. “Alih Wahana pada Kitab Patahulrahman Upaya Mendekatkan Sebuah Teks pada Masyarakatnya Kita." Jurnal Lektur Keagamaan 13(2):417-30. https:// doi.org/10.31291/jlk.v13i2.23 3

Martopangrawit. 1975. Gendhing-Gendhing Santiswara Jilid I dan II. Surakarta: ASKI Surakarta. 
Moleong, Lexy J. 2014. Metodologi Penelitian Kualitatif Edisi Revisi Bandung: PT Remaja Rosdakarya Offset. ISBN 979514-051-5.

Nugroho, Akhmad. 2018. “Komunitas Sastra Jawa: Penciptaan, Penerbitan, dan Pergelaran Tembang Macapat." Semiotika 18(2):75-87. https:// doi.org/10.19184/semiotika.v $18 \mathrm{i} 2.6540$

Nurgiyantoro, Burhan. 2018. Teori Pengkajian Fiksi. UGM PRESS.

Pradopo, Rachmat Djoko. 2010. "Pengkajian Puisi: Analisis Strata Norma dan Analisis Struktual Dan Semiotik."

Ranabumi, Raditya. 2018. “Metafora Pada Lagu Nyidham Sari Dan Yen Ing Tawang Ono Lintang." Ranah: Jurnal Kajian Bahasa 7(2):247-62.

ttps:/ / doi.org/10.26499/rnh.v7i2.659

Saheb, Saheb, Yulius Slamet, and Ahmad Zuber. 2018. "Peranan Modal Sosial Bagi Petani Miskin Untuk Mempertahankan Kelangsungan Hidup Rumah Tangga di Pedesaan Ngawi (Studi Kasus di Desa Randusongo Kecamatan Gerih Kabupaten Ngawi Provinsi Jawa Timur)." Jurnal Analisa Sosiologi 2(1).

Siahaan, Muhammad Donni Lesmana. 2019. "Mengukur Tingkat Kepercayaan Sistem Zakat Online Menggunakan Technology Acceptance Model (Tam) di Kalangan Masyarakat Kampus." Jurnal Abdi Ilmu 1(2):1-10.

https:/ / doi.org/10.20961/jas.v2i1.173
82

Suarta, I. Made. 2018. “Nilai-Nilai Filosofis Didaktis, Humanistis, dan Spiritual dalam Kesenian Tradisional Macapat Masyarakat Bali." Mudra Jurnal Seni Budaya 33(2):191-99.

https:/ / doi.org/10.31091/mudra.v33i 2.364

Surbono, Wahyu, and Sutiyono. 2018. “Bentuk dan Makna Simbolik Tembang dalam Konteks Upacara Rebo Pungkasan Kembul Sewu Dulur." Jurnal Pustaka Budaya 5(2):4251.

https:/ / doi.org/10.31849/pb.v5i2.157 7

Sutopo, H. B. 2002. "Metode Penelitian Kualitatif. Dasar dan Teori Terapannya Dalam Penelitian."

Suyoto, Timbul Haryono, and Hastanto. 2015. "Estetika Bawa dalam Karawitan Gaya Surakarta." Resital: Jurnal Seni Pertunjukan 16(1):36-51.

https:/ / doi.org/10.24821/resital.v16i1 .1273

Wahid, Amirul Nur, and Kundharu Saddhono. 2017. "Ajaran Moral dalam Lirik Lagu Dolanan Anak." Mudra Jurnal Seni Budaya 32(2). https://doi.org/10.31091/mudra.v32i $\underline{2.107}$

Zakaria, Indra, and Listiyaningsih. 2016. "Penanaman Sikap Sopan Santun Melalui Keteladanan Guru di SMP Negeri 1 Buduran Kabupaten Sidoarjo." Kajian Moral dan Kewarganegaraan 2(4). 